\title{
Tyrosine Hydroxylase Expression in Primary Cultures of Olfactory Bulb: Role of L-Type Calcium Channels
}

\author{
Elena Cigola, Bruce T. Volpe, Jong Wha Lee, Linda Franzen, and Harriet Baker \\ Cornell University Medical College at The Burke Medical Research Institute, White Plains, New York, 10605
}

Sensory activity mediates regulation of tyrosine hydroxylase (TH), the first enzyme in the dopamine biosynthetic pathway, in the rodent olfactory bulb. The current studies established for the first time primary cultures of neonatal mouse olfactory bulb expressing $\mathrm{TH}$ and tested whether L-type calcium channels mediate the activity-dependent regulation of the dopamine phenotype. After $1 \mathrm{~d}$ in vitro (DIV), a small population of $\mathrm{TH}-$ immunostained neurons that lacked extensive processes could be demonstrated. After an additional 2 DIV in serum-free medium, the number of TH neurons had doubled, and they exhibited long interdigitating processes. Membrane depolarization for $48 \mathrm{hr}$ with $50 \mathrm{~mm} \mathrm{KCl}$ produced a further 2.4-fold increase in the number of $\mathrm{TH}$-immunoreactive neurons compared with control cultures. Increased TH neuron number required at least $36 \mathrm{hr}$ of exposure to $\mathrm{KCl}$. Forskolin, which increases intracellular cAMP levels, induced a 1.5- to 1.6-fold increase in the number of $\mathrm{TH}$-immunostained neurons. Combined treatment with $\mathrm{KCl}$ and forskolin was not additive. Nifedipine, an L-type calcium channel blocker, completely prevented the depolarization-mediated increase in TH expression but did not block the response to forskolin. Treatment with Bay K8644, an L-type calcium channel agonist, also significantly increased the number of $\mathrm{TH}$-expressing neurons. Depolarization also induced alterations in neuritic outgrowth, resulting in a stellate versus an elongate morphology that, in contrast, was not prevented by nifedipine. These results are the first demonstration that in vitro, as in vivo, depolarization increases TH expression in olfactory bulb and that L-type calcium channels mediate this activitydependent regulation of the dopamine phenotype.

Key words: tyrosine hydroxylase; olfactory bulb; calcium; depolarization; primary cultures; dopamine; cAMP; L-type calcium channel; Bay K8644
Tyrosine hydroxylase (TH) is expressed in periglomerular dopamine neurons intrinsic to the olfactory bulb (Halasz et al., 1977; Baker et al., 1983). These neurons, hypothesized to modulate mitral cell excitability, receive excitatory glutamatergic input from olfactory receptor cells (Trombley and Westbrook, 1990; Berkowicz et al., 1994). TH expression developed concurrently with patterned synaptic activity between receptor and mitral cells (Gesteland et al., 1982; Baker and Farbman, 1993). In adults, reduced afferent activity produced by either primary afferent denervation or sensory deprivation resulted in profound decreases in TH expression (Nadi et al., 1981; Baker et al., 1983, 1993; Stone et al., 1990, 1991; Cho et al., 1996; Cummings et al., 1997). The mechanisms by which synaptic afferent activity either initiate or maintain olfactory bulb TH expression during development and in the adult have yet to be delineated.

Both basal and inducible TH gene regulation, previously investigated in PC12 cells and cultures of adrenal medullary chromaffin cells, occurred through several sites in the $\mathrm{TH}$ promoter, including the cAMP response element (CRE) (Kilbourne and Sabban, 1990; Fung et al., 1992; Kilbourne et al., 1992; Yoon and Chikaraishi, 1992; Kim et al., 1993; Lazaroff et al., 1995; Sabban, 1997). The CRE also acts as a calcium responsive element (CaRE). Treatments that increased intracellular calcium levels, veratridine, calcium ionophores, and depolarization also modu-

\footnotetext{
Received April 2, 1998; revised July 9, 1998; accepted July 16, 1998.

This work was supported by National Institutes of Health Grant AG09686 (H.B.). We thank Dr. Alan Blau for advice on the statistical analysis.

Correspondence should be addressed to Dr. Harriet Baker, Cornell University Medical College at The Burke Medical Research Institute, White Plains, New York 10605.

Copyright (ㄷ) 1998 Society for Neuroscience $\quad 0270-6474 / 98 / 187638-12 \$ 05.00 / 0$
}

lated TH expression (Kilbourne and Sabban, 1990; Kilbourne et al., 1992; Sabban, 1997). Depolarization-mediated induction of TH gene expression also occurred via the AP1 site in the TH promoter (Nagamoto-Combs et al., 1997). Recent studies also demonstrated an important role for L-type calcium channels in depolarization-induced expression of immediate early genes such as c-fos (Murphy et al., 1991), which bind to the AP1 site (Sheng and Greenberg, 1990; Sheng et al., 1990). Significantly, in olfactory bulb dopamine neurons, decreased expression of fos family genes paralleled the downregulation of $\mathrm{TH}$ expression, suggesting an important role for calcium in $\mathrm{TH}$ gene regulation (Guthrie et al., 1993; Guthrie and Gall, 1995a,b; Jin et al., 1996).

Neonatal olfactory bulb cultures were chosen to study the relationship between depolarization and $\mathrm{TH}$ expression for several reasons. First, both in vivo and in vitro studies showed cell type-specific regulation of the dopaminergic phenotype that differed between olfactory bulb and other brain dopaminergic systems (Weiser et al., 1993; Lazaroff et al., 1995; Tinti et al., 1996). Second, although all previous studies of olfactory bulb $\mathrm{TH}$ (Denis-Donini, 1989; McMillian et al., 1994) used primary cultures obtained from embryonic tissues, significant numbers of TH-expressing cells cannot be demonstrated until gestational day 18 (Baker and Farbman, 1993). Thus, to study authentic and not ectopic phenotypic expression, postnatal neurons must be cultured. Last, because most periglomerular neurons have birth dates between 1 and 4 days postnatal (Hinds, 1968: Bayer, 1983), robust $\mathrm{TH}$ expression could be expected in cultures of neonatal olfactory bulb.

Thus, the current studies used primary cultures derived from neonatal olfactory bulbs to delineate whether depolarization and cAMP mediate TH gene regulation in the olfactory bulb. Also- 

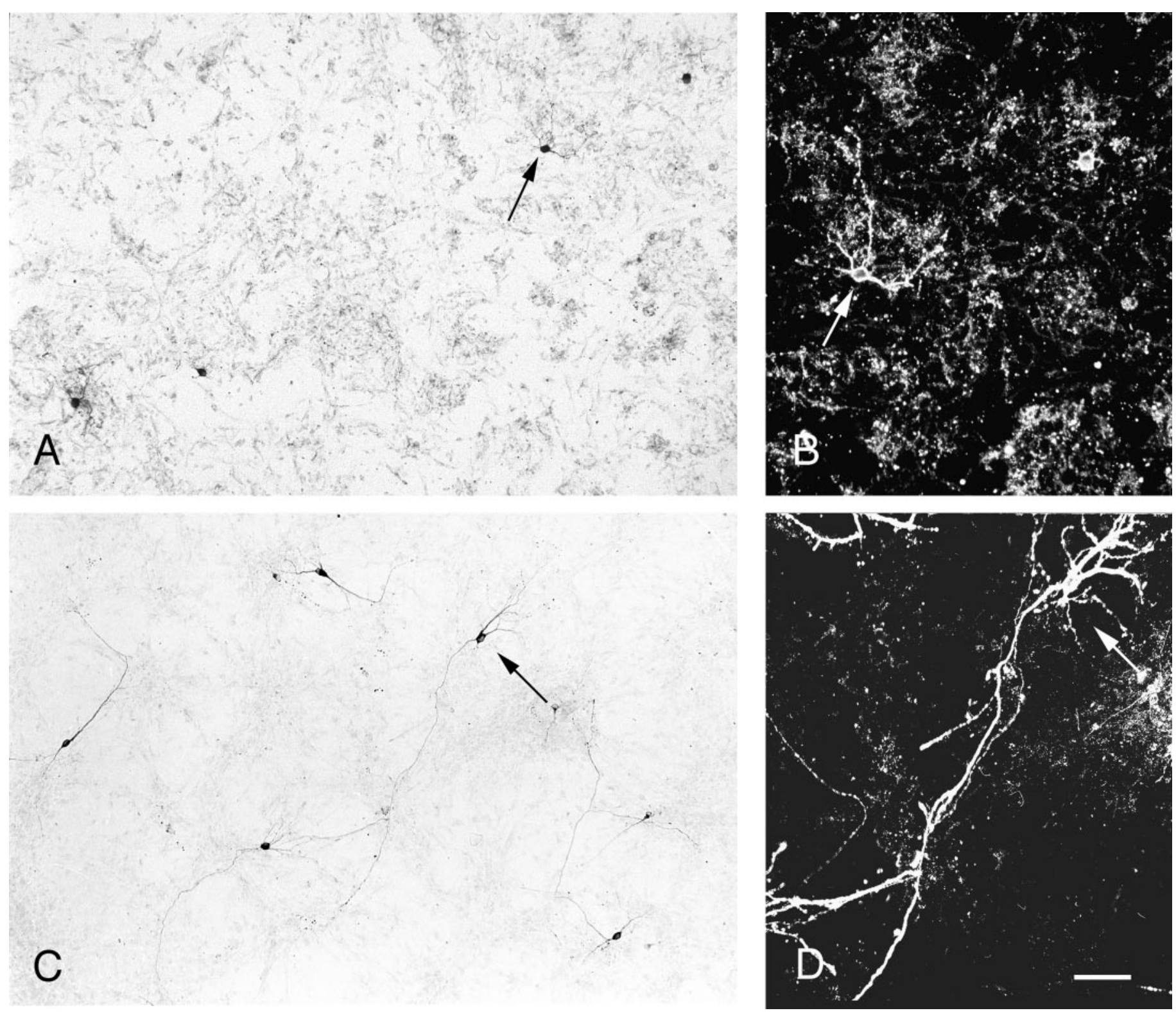

Figure 1. Time-dependent development of TH expression in culture. $A$, A bright-field photomicrograph illustrates olfactory bulb cultures after 24 hr (time 0 ) in serum-containing medium. TH-immunoreactive cells are dispersed throughout the culture but have few relatively short processes that do not fasciculate. $B$, Dark-field photomicrograph emphasizes the paucity of processes. $C$, After an additional $48 \mathrm{hr}$ in serum-free control medium (see Materials and Methods), the increased number of TH-immunostained neurons displayed many long interdigitating processes, illustrated in $D$. Arrows in $A$ and $C$ indicate the same cells shown at higher magnification in $B$ and $D$. Scale bar (in $D$ ): $A, C, 100 \mu \mathrm{m} ; B, D, 65 \mu \mathrm{m}$.

investigated was a role for L-type calcium channels in activitydependent regulation of TH expression.

\section{MATERIALS AND METHODS}

Animals. $\mathrm{C} 57 \mathrm{Bl} / 6 \mathrm{~J}$ females and $\mathrm{CBA} / \mathrm{J}$ males, originally purchased from The Jackson Laboratory (Bar Harbor, ME), were bred in house to obtain mouse pups of appropriate age. Mice were housed in an approved animal facility under constant temperature, cycled lighting (12 hr light/dark cycle), and access to food and water ad libitum. All procedures were performed under protocols approved by the Cornell University Institutional Animal Care and Use Committee and conformed to National Institutes of Health guidelines.

Cell culture. Cell culture was performed according to previously published methods with slight modification (Iacovitti et al., 1992). Olfactory bulbs were collected from a single litter of 2-d-old mouse pups (6-10 per isolation), cleaned of investing membranes, minced, and dissociated at $37^{\circ} \mathrm{C}$ for $30 \mathrm{~min}$ in trypsin-EDTA $(0.1 \%$ in HBSS) (Life Technologies, Grand Island, NY). After trituration with a fire-polished Pasteur pipette, the cells were rinsed with medium (DMEM high-glucose medium) containing $10 \%$ fetal calf serum (Life Technologies), $10 \mu \mathrm{M}$ L-glutamine (Sigma, St. Louis, MO), $0.6 \%$ glucose, and 1\% penicillin-streptomycin (Sigma). To avoid edge effects (Takeshima et al., 1996), $100 \mu$ l containing $0.2-0.3 \times 10^{6}$ cells were plated in the center of each well in a fourchamber slide (Nunc, Naperville, IL), previously coated overnight with a solution of polyornithine $(1 \mathrm{mg} / \mathrm{ml}$; Sigma) in $0.15 \mathrm{M}$ borate buffer. After $30 \mathrm{~min}$ to allow the cells to attach, $400 \mu \mathrm{l}$ of medium was added to each well, and the slides were placed in a humidified $5 \% \mathrm{CO}_{2}-95 \%$ air incubator at $37^{\circ} \mathrm{C}$. After $24 \mathrm{hr}, 0 \mathrm{hr}$ with respect to treatments, the medium was replaced with a serum-free neurobasal medium (Life Technologies) containing 1\% N-2 supplement (Life Technologies), $0.5 \mathrm{~mm}$ L-glutamine (Sigma), $25 \mu \mathrm{M}$ L-glutamic acid (Sigma), and the different treatments (see below). Defined serum-free medium was used to obviate the possibility that the observed responses were mediated by the actions 


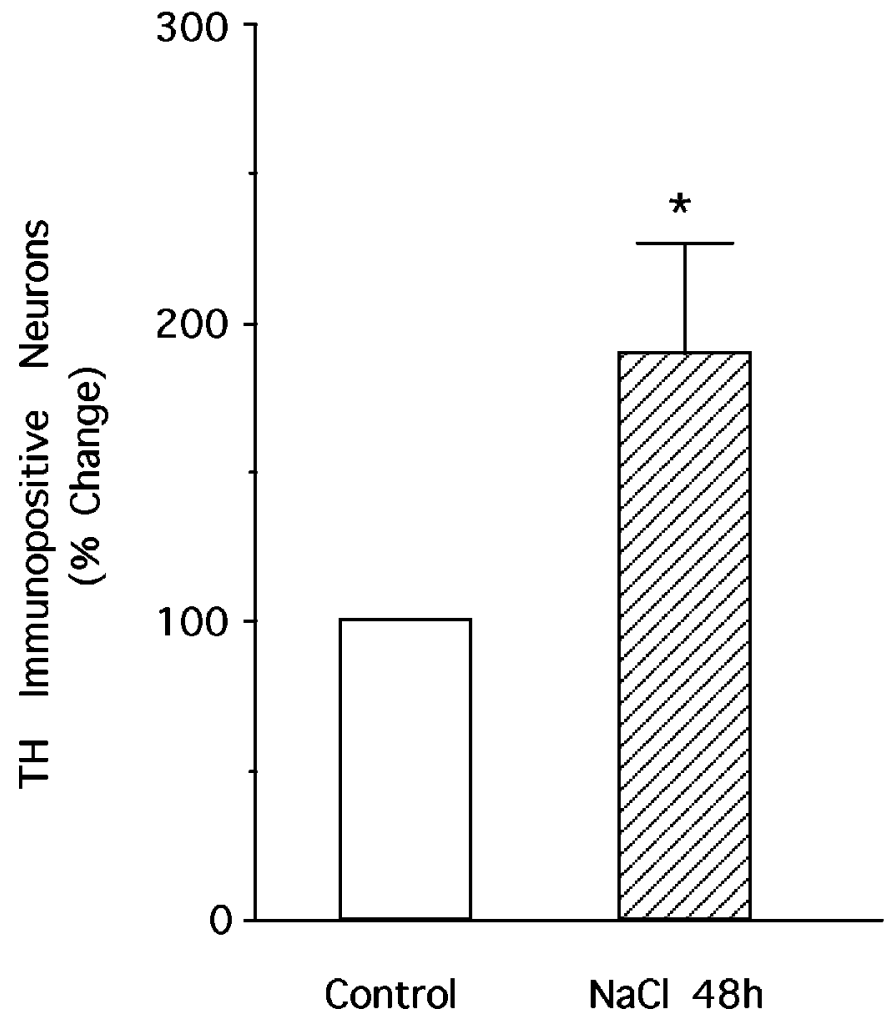

Figure 2. Significant $(p<0.001)$ increase in the number of THimmunostained neurons after $48 \mathrm{hr}$ in control (NaCl-containing) serumfree medium. Control cultures (time 0) contained $4.6 \pm 0.65 \mathrm{TH}$ immunopositive cells $/ \mathrm{mm}^{2}$. Data were obtained from three experiments performed in triplicate. Comparisons were made by a paired Student's $t$ test.

Table 1. Quantitative analysis of cell types in olfactory bulb cultures

\begin{tabular}{lcc} 
Cell type & $\mathrm{NaCl}^{\mathrm{a}}$ & $\mathrm{KCl}$ \\
\hline Neurons & $1475 \pm 157$ & $1329 \pm 324$ \\
Glia & $452 \pm 47$ & $569 \pm 81$ \\
Total nuclei & $2344 \pm 164$ & $2422 \pm 91$ \\
TH-immunopositive & $8.75 \pm 1.16$ & $18.96 \pm 2.12^{*}$
\end{tabular}

$\overline{\text { For each analysis condition, data were averaged from at least two wells obtained }}$ from at least three experiments (cultures prepared from different isolations). ${ }^{*} p<$ 0.005 .

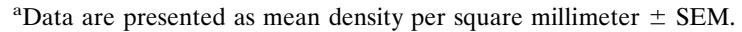

of unknown serum components. The cells were fixed for 20 min with $4 \%$ buffered formaldehyde either immediately after or $48 \mathrm{hr}$ after replacement of the medium.

Treatments. To mimic in vivo afferent stimulation, parallel cultures were either depolarized with $50 \mathrm{mM} \mathrm{KCl}$ or, as a control, an equimolar concentration of $\mathrm{NaCl}$. Treatments were started simultaneously with the replacement of the serum-containing medium with the serum-free medium and interrupted $48 \mathrm{hr}$ later by fixation of the cells. In some cultures, depolarization was interrupted after either $4,8,16,24$, or $36 \mathrm{hr}$ by replacing the $\mathrm{KCl}$-containing medium with $\mathrm{NaCl}$-containing medium. Medium was replaced at the same time points in control cultures. To determine the response to increased intracellular levels of cAMP, some cultures were stimulated with $10 \mu \mathrm{M}$ forskolin in DMSO (Tinti et al., 1996). An equal concentration of DMSO was used as a control. To investigate the role of calcium in the induction of TH, nifedipine (Sig$\mathrm{ma})$, an L-type calcium channel blocker (10 $\mu \mathrm{M}$ in DMSO), was added to the serum-free medium $30 \mathrm{~min}$ before either $\mathrm{KCl}$ or forskolin treatments and to the respective control cultures (Miller, 1987). Cultures also were treated for $48 \mathrm{hr}$ with the L-type calcium channel agonist Bay K8644
( $1 \mu \mathrm{M}$ in DMSO; Sigma) either alone or in the presence of $15 \mathrm{mM} \mathrm{KCl}$ (Brosenitsch et al., 1998), added with the serum-free medium (Nowycky et al., 1985). Because Brosenitsch et al. (1998) reported that low-level depolarization, which did not alter TH expression, potentiated the effects of Bay K8644 in primary sensory neurons, similar treatments were used in the current studies. All cultures were harvested after $48 \mathrm{hr}$ in serumfree medium unless otherwise stated.

Immunocytochemistry. Fixed cultures were rinsed two times for $10 \mathrm{~min}$ each in PBS, preincubated $30 \mathrm{~min}$ in $0.1 \mathrm{M}$ PBS with $1 \%$ bovine serum albumin (BSA) and $0.2 \%$ Triton $\mathrm{X}-100$, washed two times for $10 \mathrm{~min}$ each in $0.1 \mathrm{M}$ PBS with $0.5 \% \mathrm{BSA}$, and incubated overnight in primary antisera to either TH $(1: 25,000)$, glial fibrillary acidic acid (GFAP) $(1: 12,000)$, or neuron-specific $\beta$-tubulin isotype III $(1: 10,000)$. Specificity of the antisera was established previously (Baker et al., 1983; Debus et al., 1983; Grill and Pixley, 1997). After two 10 min washes in 0.1 м PBS and $0.5 \%$ BSA, cells were incubated for $1 \mathrm{hr}$ in secondary antibody of either biotinylated anti-rabbit or anti-mouse IgG. The wells were then washed twice in $0.1 \mathrm{~m}$ PBS- $-0.5 \%$ BSA and further incubated for $1 \mathrm{hr}$ in the avidin-biotin complex (Elite Kit) purchased from Vector Laboratories (Burlingame, $\mathrm{Ca}$ ). Antigens were visualized by incubation for $5 \mathrm{~min}$ in $0.05 \% 3,3^{\prime}$-diaminobenzidine $\mathrm{HCl}$ and $0.003 \%$ hydrogen peroxide. Some wells were counterstained with Mayer's hematoxylin, and all slides were dehydrated through graded alcohols, cleared in xylene, and coverslipped with Permount (Fisher Scientific, Fairlawn, NJ).

Cell counting procedures. The number of TH-immunolabeled cells was counted in at least 20 fields per well at $160 \times$. In most preparations, more than five TH-immunoreactive cells were found in the same field of view under basal conditions. The area sampled in each well was $\geq 11 \mathrm{~mm}^{2}$. Cells were counted only if they exhibited a clearly stained cell body. Similar counting procedures were used for evaluating the density of GFAP- and $\beta$-tubulin-immunoreactive cells. Total nuclear density in hematoxylin-stained cultures was estimated at $400 \times$ magnification in at least 20 fields.

To standardize the changes in the number of immunopositive $\mathrm{TH}$ cells, the data were expressed in terms of percent of increase relative to within culture controls instead of absolute numbers. For each treatment condition, data were averaged from at least four wells obtained from at least three experiments (cultures prepared from different isolations).

Measurement of neurite length. Neurite length was measured by visualizing the TH-immunopositive neurons in dark-field conditions at $100 \times$. In each well, at least $50 \mathrm{TH}$-immunopositive neurons were analyzed for neurite length. The longest neurite on each TH-positive cell was measured as an estimate of the altered morphology. These judgments were validated between two examiners. Measurement of the neurite length was accomplished by transferring the dark-field image to a digital image on which a cursor was used to trace the longest neurite for each neuron (Ibas20; Zeiss, Thornwood, NY). Programs, which have been validated, transformed cursor lengths into micrometers (Volpe et al., 1995; Saji et al., 1996).

Statistical analysis. All values are presented as mean \pm SEM. Sample sizes $(n)$ are listed in the text or in the legend to each figure. ANOVA was used to test for multiple comparisons among independent groups of data. The presence of significant differences between groups was then determined by the Bonferroni method (Wallenstein et al., 1980). Comparisons between data with only two variables were performed by a paired Student's $t$ test (Wallenstein et al., 1980). $p<0.05$ was considered to be significant.

\section{RESULTS}

\section{Tyrosine hydroxylase immunostaining in culture}

After $24 \mathrm{hr}$ in a serum-containing medium, TH-immunoreactive neurons were dispersed throughout the culture (Fig. 1A). The cells generally displayed strong immunoreactivity, were round in shape, and lacked elaborate processes (Fig. $1 B$ ). With an additional $48 \mathrm{hr}$ in vitro in a serum-free control ( $\mathrm{NaCl}$-containing) medium, TH-immunoreactive cells exhibited variable morphology ranging from round to fusiform and were now characterized by the presence of long complex processes (Fig. $1 C, D$ ). To examine the consequences of time in vitro on the number of $\mathrm{TH}$ containing neurons, immunostained cells were counted either 24 hr (time 0 with respect to treatments) after plating or after an 

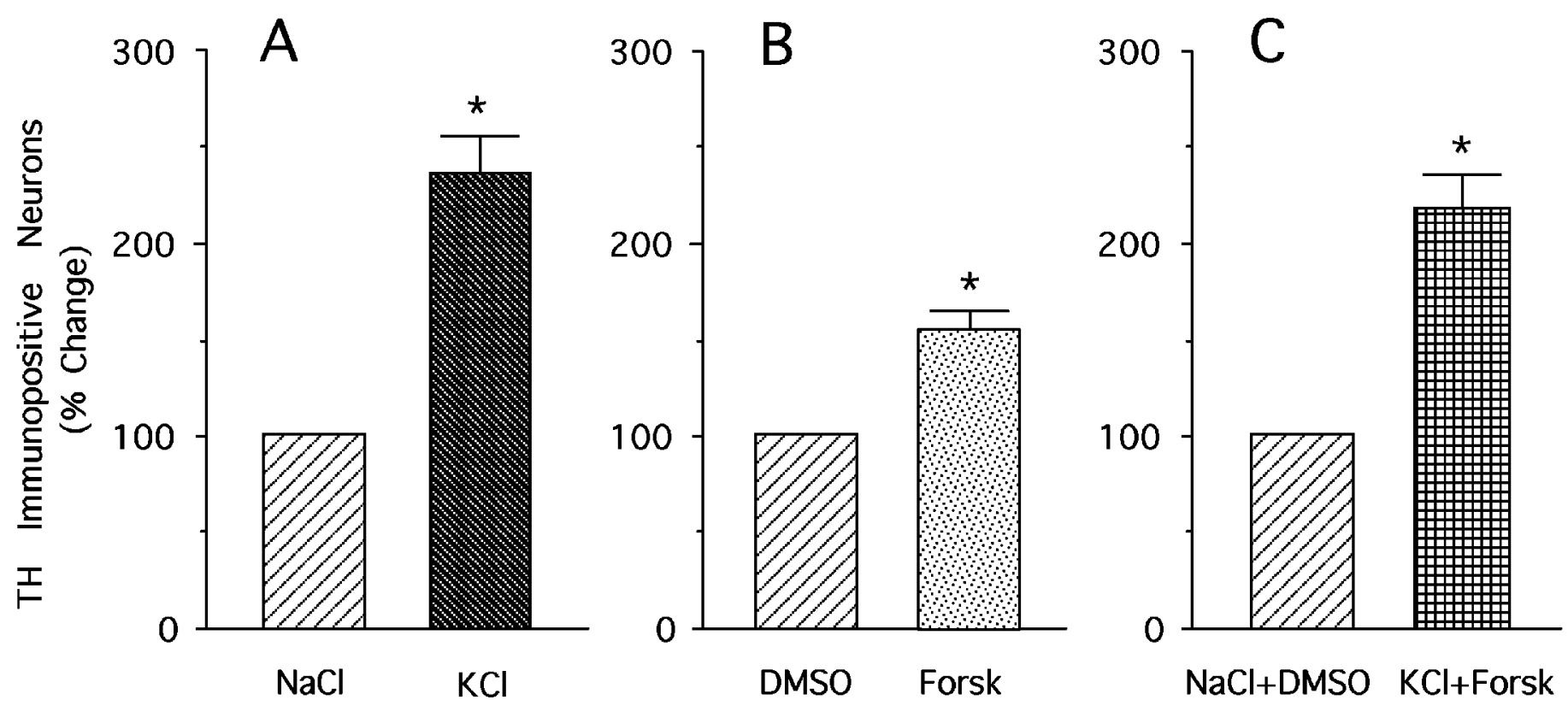

Figure 3. Depolarization- and forskolin-induced expression of TH. $A$, Membrane depolarization with $50 \mathrm{~mm} \mathrm{KCl} \mathrm{for} 48 \mathrm{hr}$ produces a significant ( $p<$ 0.001) 2.4-fold increase in the number of TH-immunoreactive neurons compared with control NaCl-treated cultures. The latter contained $8.75 \pm 1.2$ TH-immunopositive cells $/ \mathrm{mm}^{2}$. Data were obtained from four experiments performed in at least triplicate. B, Forskolin (Forsk) produced a significant $(p<0.001)$ 1.6-fold induction in the number of TH-immunostained neurons compared with control DMSO-treated cultures. The mean number of TH-immunoreactive cells in DMSO control cultures was $10.35 \pm 1.99$ per square millimeter. Four experiments performed in at least triplicate were analyzed to produce these data. $C$, Combined treatment with both $\mathrm{KCl}$ and forskolin was not additive, producing no further induction in the number of TH-immunostained neurons. DMSO-NaCl-treated control cultures had $8.12 \pm 0.46 \mathrm{TH}$-immunopositive cells $/ \mathrm{mm}^{2}$. Comparisons were made by a paired Student's $t$ test.

additional $48 \mathrm{hr}$ in the serum-free control medium. The number of TH-immunostained cells increased almost twofold at $48 \mathrm{hr}$ $(p<0.005)$ compared with cells exposed only to serumcontaining medium for $24 \mathrm{hr}$ (time 0) (Fig. 2). Although a significant increase occurred with time in culture, the number of $\mathrm{TH}$-immunoreactive cells at $48 \mathrm{hr}$ represented only $0.37 \%$ of the total number of cells in each well (Table 1). The relative proportion of TH stained to the total number of neurons was similar to that reported previously in other primary cultures of dopamine neurons (McMillian et al., 1994).

\section{$\mathrm{KCl}$-induced increase in number of TH-immunopositive neurons}

Continuous depolarization for $48 \mathrm{hr}$ produced a 2.4-fold ( $p<$ $0.001)$ increase in the number of $\mathrm{TH}$-immunostained neurons compared with control (NaCl-treated) cultures (Fig. 3A). The immunopositive neurons, as in control wells, were dispersed throughout the cultures; however, depolarization altered the morphology of their processes (see below).

Control and KCl-treated cultures also were examined to confirm the specificity of the depolarization-induced increase in the number of TH neurons. Both the density of neurons stained with anti- $\beta$-tubulin and glial cells stained with anti-GFAP showed no significant differences $(p>0.05)$ between $\mathrm{KCl}$ - and NaCl-treated cultures (Table 1$)$. There was no alteration $(p>0.05)$ in the total number of cells between the two treatment conditions, evaluated by hematoxylin staining of nuclei (Table 1). Moreover, the magnitude of the increase in the number of $\mathrm{TH}$-immunostained neurons was independent of both plating density and the number of TH neurons in control cultures (data not shown).

\section{Time course of $\mathrm{TH}$ induction}

To determine whether shorter-term exposure to $\mathrm{KCl}$ was sufficient to increase $\mathrm{TH}$ gene expression, cells were treated with $\mathrm{KCl}$ for either 4, 8, 16, 24, 36, or $48 \mathrm{hr}$. Depolarization was terminated by replacement of the $\mathrm{KCl}$-containing medium with the $\mathrm{NaCl}$ containing medium. All cultures were harvested $48 \mathrm{hr}$ after the onset of treatment. The medium was replaced at the same time in the control cultures. No significant increase was seen at 16 and 24 hr of stimulation (Fig. 4). The minimal duration of depolarization that produced a significant increase (1.47-fold) in TH immunoreactivity was $36 \mathrm{hr}(p<0.001)$. The peak increase occurred at $48 \mathrm{hr}(p<0.001)$, which was the longest time investigated. The $\mathrm{KCl}$-induced increase obtained at $48 \mathrm{hr}$ did not differ between this and other experiments. Replacement of control medium with fresh NaCl-containing medium did not alter the number of THimmunopositive neurons compared with cultures maintained continuously in the same control medium for $48 \mathrm{hr}$ (data not shown).

\section{Nifedipine treatment blocks $\mathrm{KCl}$-induced increase in TH expression}

Depolarization-induced increases in $\mathrm{TH}$ expression in other model systems result at least in part from an increase in intracellular calcium (Sabban, 1997). To examine the role of calcium in the induction of TH expression by depolarization in the olfactory system, parallel wells were treated for $48 \mathrm{hr}$ with either $\mathrm{KCl}$ or $\mathrm{NaCl}$ alone or in the presence of nifedipine, a drug that inhibits calcium entry through L-type calcium channels. Nifedipine completely prevented the depolarization-induced 2.1-fold increase $(p<0.05)$ in the number of TH-immunostained neurons (Fig. $5 A$ ). Pretreatment with the calcium blocker did not alter the 


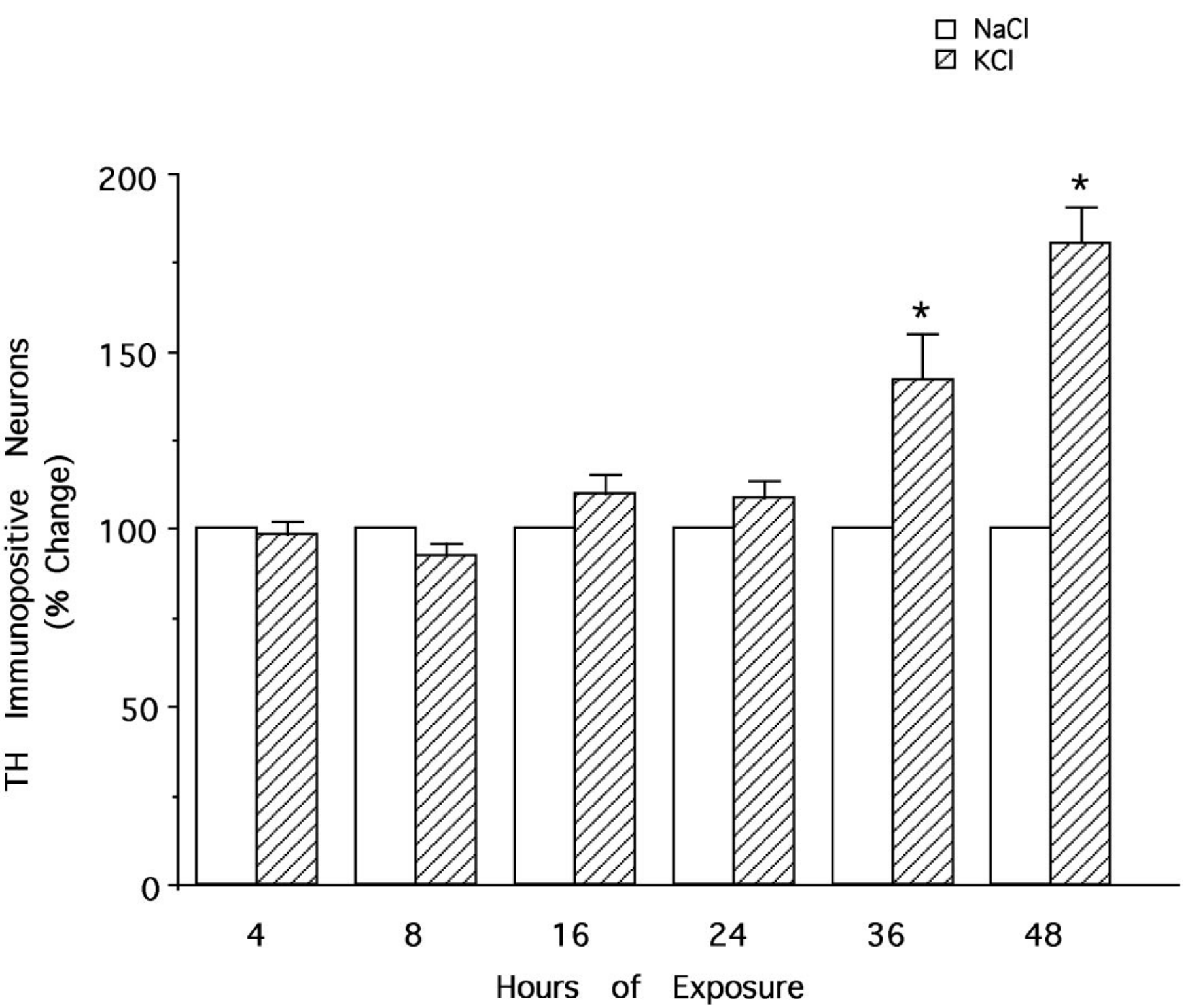

Figure 4. Time dependence of depolarization-induced TH expression. An increase in the number of TH-immunostained neurons occurred only when cultures were treated 36 and $48 \mathrm{hr}$ with $50 \mathrm{mM} \mathrm{KCl}$ (hatched bars). Cultures were exposed to $\mathrm{KCl}$ for the time indicated and then incubated in control medium until fixation at $48 \mathrm{hr}$ after the onset of stimulation. Values were calculated relative to their respective control culture (open bars). In control cultures, the NaCl-containing medium was replaced at the same time as in the KCl-treated cultures and maintained until $48 \mathrm{hr}$. Data were obtained from three experiments performed in duplicate.

number of immunostained neurons in $\mathrm{NaCl}$-treated cultures (Fig. 5A).

\section{Bay K8644 treatment mimics $\mathrm{KCl}$-induced increase in TH expression}

To establish whether a selective L-type calcium channel agonist alone was able to induce TH-expression, cultures were treated with $1 \mu \mathrm{M}$ Bay K8644 added to the serum-free medium. Confirming the role of L-type calcium channels, this study showed that compared with the vehicle DMSO, Bay K8644 alone produced a significant increase (mean $\pm \mathrm{SE} ; 1.43 \pm 0.09$-fold; $p<0.05 ; n=$ 18 ) in the number of TH-immunoreactive neurons after $48 \mathrm{hr}$ of treatment. In agreement with the findings of Brosenitsch et al., (1998) that slight depolarization augmented the effects of Bay $\mathrm{K} 8644$, the agonist was added in the presence of a concentration of $\mathrm{KCl}(15 \mathrm{~mm})$, which alone did not increase the number of
TH-immunostained neurons $(p>0.05)$, and produced a $2.1 \pm$ 0.27 -fold increase $(p<0.05 ; n=9)$ in the number of THimmunoreactive neurons compared with control cultures treated with DMSO and $\mathrm{KCl}$. In this series of experiments, treatment with $50 \mathrm{mM} \mathrm{KCl}$ produced the expected $2.1 \pm 0.3$-fold increase $(p<0.05 ; n=14)$ in the number of TH-immunoreactive neurons.

\section{Forskolin-induced increase in number of TH-immunostained neurons}

Forskolin, an adenylate cyclase agonist, at a maximally effective concentration $(10 \mu \mathrm{M})$ produced a 1.6-fold increase in the number of TH-immunopositive neurons (Fig. $3 B$ ) compared with control (DMSO-treated) cultures $(p<0.005)$. To determine whether depolarization and cAMP stimulated $\mathrm{TH}$ expression through either a common rate-limiting mechanism or through different 


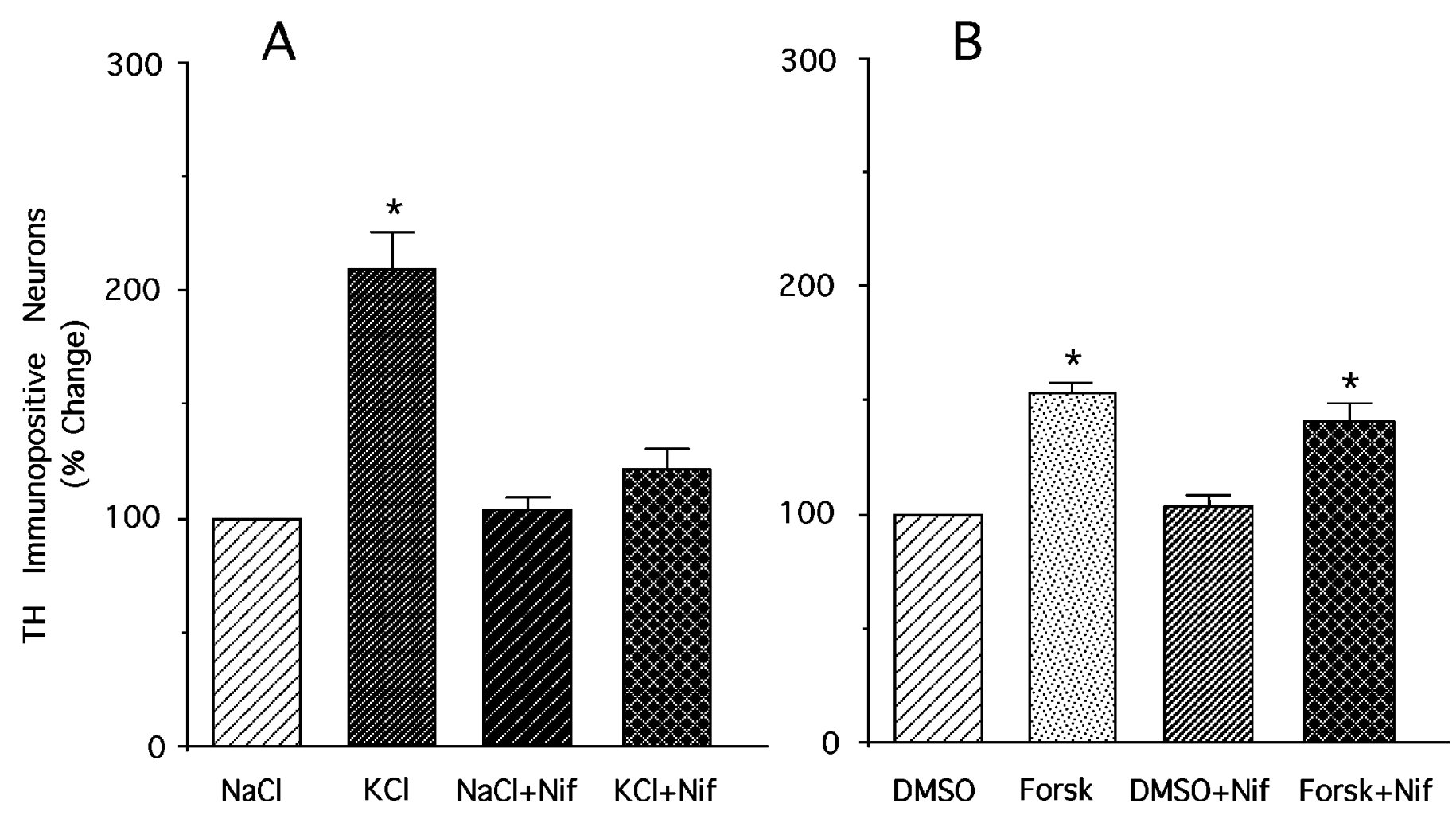

Figure 5. Nifedipine blocks KCl-induced, but not forskolin-induced, increase in TH expression. $A$, The 2.1-fold increase $(p<0.001)$ in the number of TH-immunopositive neurons was prevented by nifedipine pretreatment, resulting in the same number of TH-immunopositive cells in NaCl-treated and $\mathrm{KCl}$ plus nifedipine-treated cultures. Pretreatment with nifedipine did not alter the number of cells in control NaCl-treated cultures $(p>0.05)$. The mean number of immunopositive cells per square millimeter in NaCl-treated cultures was $10.49 \pm 2.0$. Data were obtained from four experiments performed in triplicate. $B$, The forskolin-induced increase in TH-immunopositive neurons continued in cultures pretreated with nifedipine $(p<0.01)$. Nifedipine does not alter the number of stained cells in control DMSO-treated cultures. The mean number of immunopositive cells per square millimeter in DMSO-treated cultures was $13.87 \pm 2.1$. Data are expressed relative to control in either NaCl-treated $(A)$ or DMSO-treated $(B)$ cultures. Statistical comparisons were made by ANOVA with a Bonferroni post hoc test to determine significant differences between treatments.

additive mechanisms, cultures were treated with both $\mathrm{KCl}$ and forskolin. Compared with a 2.4-fold increase induced by $\mathrm{KCl}$ alone and a 1.6-fold increase produced by forskolin alone, combined treatment produced a 2.2-fold increase in the number of positive cells (Fig. 3C). The magnitude of increase did not differ significantly $(p>0.05)$ from the effects obtained with either $\mathrm{KCl}$ or forskolin alone. These findings suggest that either depolarization and cAMP stimulate TH expression through the same pathway or that depolarization produces the maximal possible increase in TH expression, which is a ceiling effect.

\section{Nifedipine does not alter forskolin-mediated TH induction}

A role for calcium also has been hypothesized for $\mathrm{TH}$ gene induction by cAMP-dependent mechanisms (Stachowiak et al., 1994; Sabban, 1997). To further examine the role of L-type calcium channels in the regulation of $\mathrm{TH}$, the effects of nifedipine were evaluated in the $\mathrm{TH}$ induction produced by forskolin. Nifedipine pretreatment did not change $(p>0.05)$ the number of TH-immunopositive neurons produced by forskolin stimulation (Fig. 5B). Addition of nifedipine to the control (DMSO-treated) cultures did not change the number of TH-immunopositive cells (Fig. 5B).

\section{$\mathrm{KCl}-$ and forskolin-induced changes in cellular and neurite morphology}

Treatment with $\mathrm{KCl}$ produced not only a change in the number of TH-expressing neurons but also in their morphology. In control cultures, TH-immunoreactive neurons usually displayed long, relatively unbranched neurites (Figs. 6 $A, 7 A$ ). After depolarization, the cells took on a stellate appearance, with more neurites and a more complex aspect (Figs. 6B,7B). However, no major change in staining intensity of $\mathrm{TH}$-immunopositive neurons was apparent after a $2 \mathrm{~d}$ treatment with $\mathrm{KCl}$. In contrast to the nifedipinemediated blockade of the KCl-induced increase in the number of neurons expressing $\mathrm{TH}$, the calcium blocker did not prevent the change in neurite morphology (Figs. 6D, 7D). Nifedipine pretreatment also did not alter neurite morphology in control cultures (Figs. 6C, 7C).

Because of the close apposition of the cells in the KCl-treated cultures, it was difficult to distinguish reliably between all the neurites of individual cells and total neurite number, and length could not be determined. Because the neurites appeared shorter in the depolarized condition, the changes in neurite morphology were assessed by determining the length of the longest process independent of their number. At $48 \mathrm{hr}$ after treatment, the longest neurites were significantly shorter in KCl-treated than $\mathrm{NaCl}$-treated cultures (Fig. 8). Examination of cultures at other treatment intervals did not reveal any apparent differences in neurite length. The alteration in neurite length was not prevented by pretreatment with nifedipine (Fig. 8).

In DMSO-treated cultures, $\mathrm{TH}$-immunopositive neurons displayed a similar morphology, as observed in $\mathrm{NaCl}$ control cultures. Neurons had long, relatively less branched neurites (Fig. $9 A, C)$. Forskolin produced both an increase in the number of 

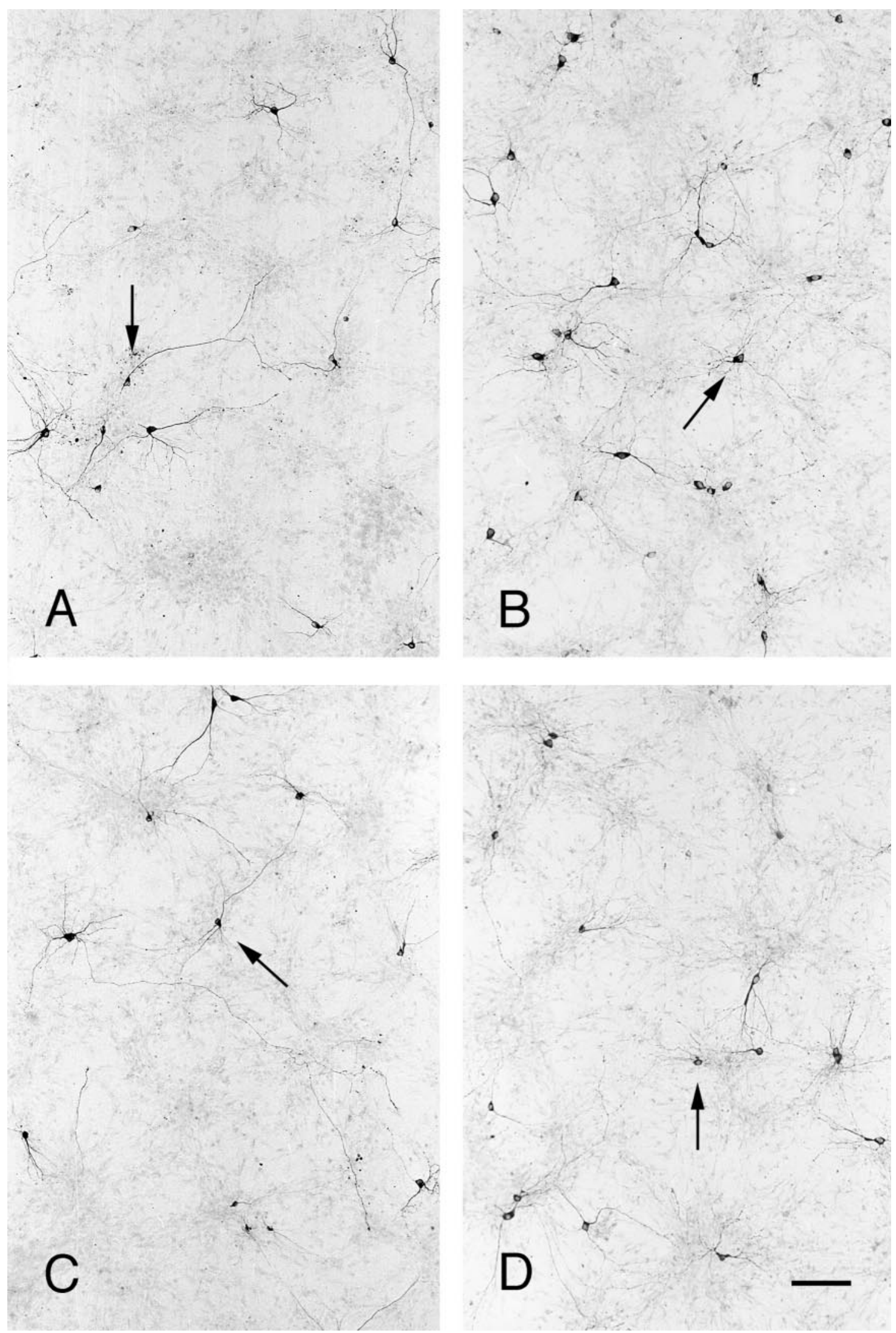

Figure 6. Bright-field micrographs illustrating the $\mathrm{KCl}$-induced increase in number of TH-immunoreactive cells and its prevention with nifedipine. The number of TH-immunostained cells increased by more than twofold in KCl-treated compared with NaCl-treated cultures ( $B$ and $A$, respectively). $D$, Nifedipine prevented the increase in the number of TH-immunostained neurons in KCl-treated cultures without altering the number of immunopositive cells in NaCl-treated control cultures $(C)$. See Figure 5 for quantitative comparisons. Arrows indicate the same cells shown at higher magnification in the corresponding panels in Figure 7. Scale bar, $100 \mu \mathrm{m}$. 

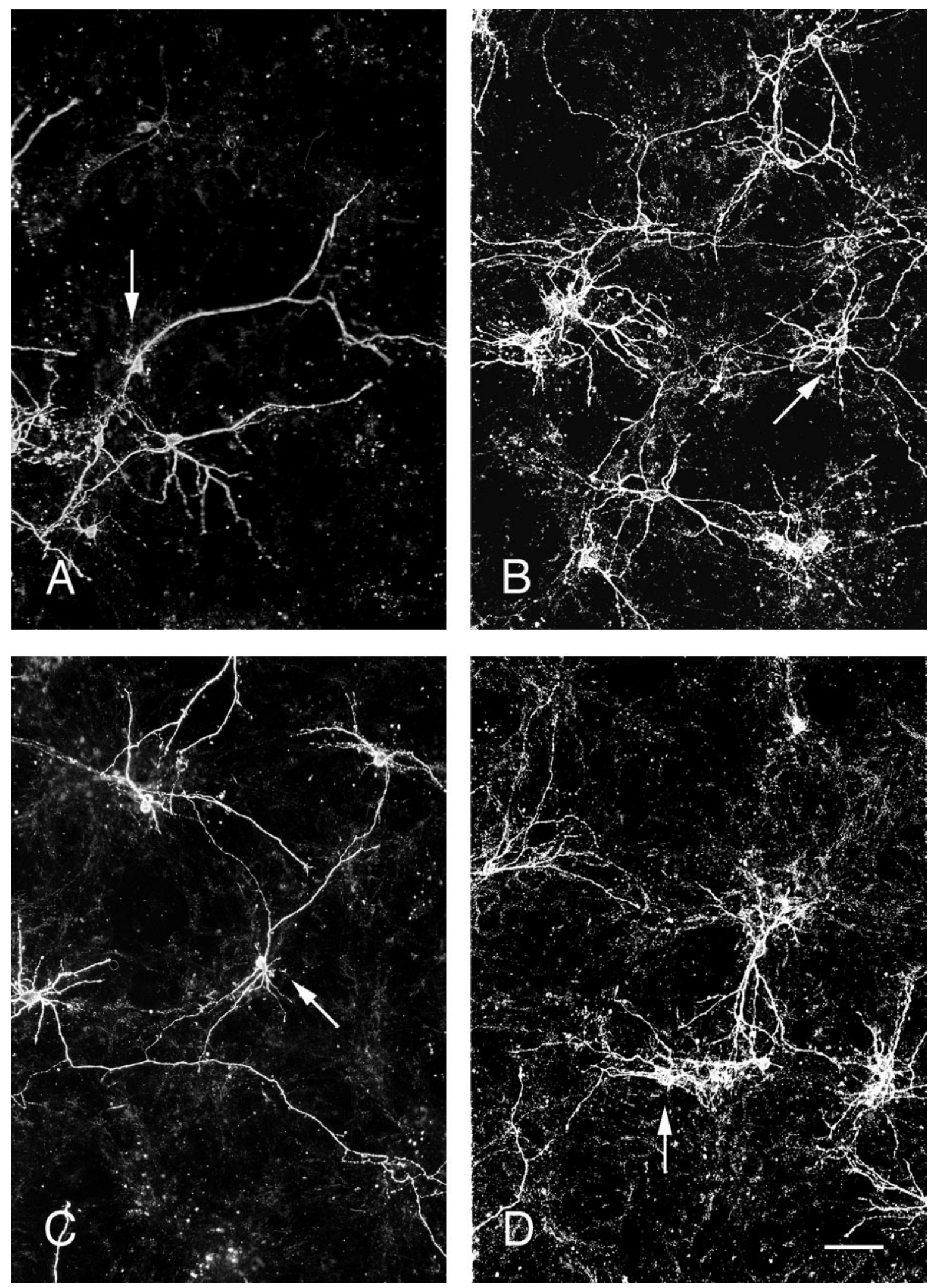

Figure 7. Dark-field photomicrographs illustrating the KCl-induced change in neurite morphology. $A$, Neurons in NaCl-treated cultures often displayed long, relatively unbranched TH-immunoreactive neurites. $B$, In contrast, depolarization produced cells with a stellate appearance resulting from the many processes of perikaryal origin and the paucity of long neurites. The morphological changes were assessed by measuring the length of the longest neurite (Fig. 8). $C$, Nifedipine did not alter neurite morphology in control cultures. $D$, The depolarization-induced change in cell morphology was not altered by nifedipine pretreatment, resulting in a continuing stellate appearance of the KCl-treated cells. Scale bar, $65 \mu \mathrm{m}$. 


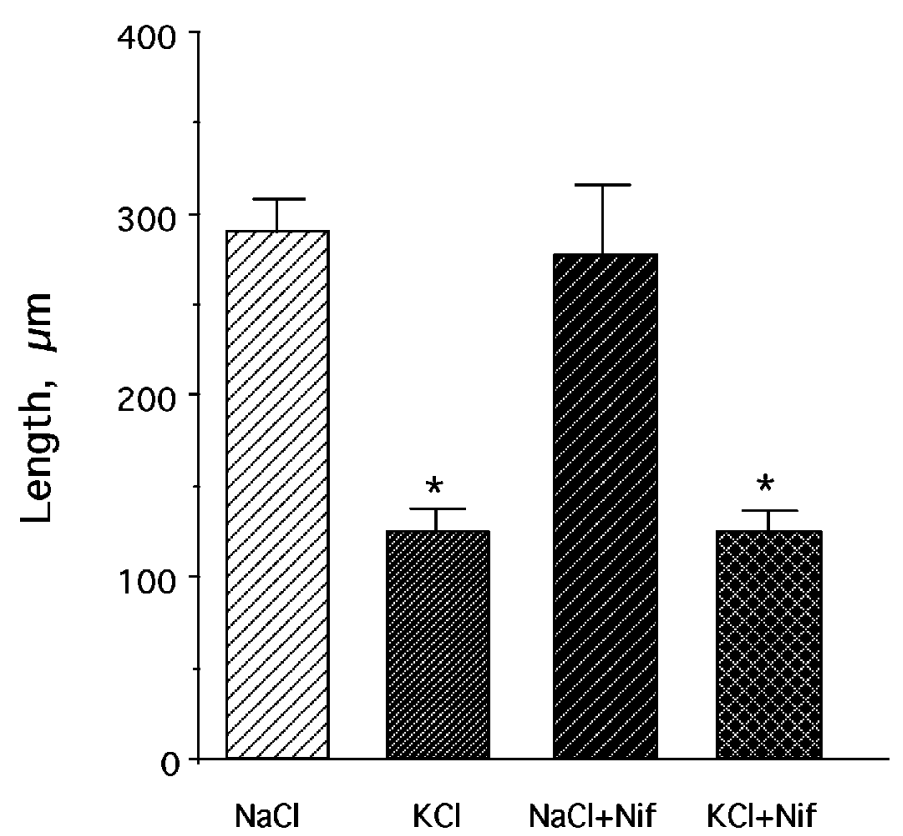

Figure 8. KCl-induced change in neurite length. The length of the longest TH-immunoreactive neurite was significantly $(p<0.001)$ reduced by treatment with depolarizing concentrations of $\mathrm{KCl}$ (Figs. 6, 7). Nifedipine pretreatment did not prevent the depolarization-induced change in neurite morphology. Data were analyzed by ANOVA using a Bonferroni post hoc test for between group comparisons. Asterisks indicates significant difference from respective control.

TH-immunoreactive cells and a stellate morphology compared with DMSO-treated cultures (Fig. 9B,D). The morphological alterations appeared comparable to those produced by depolarization and were not assessed quantitatively.

\section{DISCUSSION}

A number of in vivo studies demonstrated that expression of the dopaminergic phenotype in periglomerular neurons intrinsic to the olfactory bulb, as assessed by expression of $\mathrm{TH}$, required odor-induced afferent activity (Brunjes et al., 1985; Brunjes and Frazier, 1986; Kosaka et al., 1987; Baker, 1990; Guthrie et al., 1990; Stone et al., 1990, 1991; Baker et al., 1993; Cummings et al., 1997). In vitro studies, primarily in cell lines, indicated that membrane depolarization, which mimics afferent stimulation, modulated transcription of a number of genes, including $\mathrm{TH}$ (Kilbourne and Sabban, 1990; Kilbourne et al., 1992; Stachowiak et al., 1994; Sabban, 1997). The goal of the current studies was to investigate the mechanisms underlying depolarization-dependent regulation of $\mathrm{TH}$ expression using primary cultures derived from neonatal mouse olfactory bulb.

\section{Tyrosine hydroxylase expression in vitro}

The current studies demonstrated that TH-immunoreactive neurons occurred $1 \mathrm{~d}$ after plating in serum-containing medium in primary cultures prepared from 2 d-old mouse pups. The presence of short, unbranched processes indicated the relatively undifferentiated state of these neurons. After an additional $48 \mathrm{hr}$ in serum-free medium, the number of $\mathrm{TH}$-immunostained neurons increased by almost twofold. Because the isolation of cells results in deafferentation of the periglomerular neurons, a process that downregulates TH expression in vivo (Nadi et al., 1981; Baker et al., 1983, 1984), the presence of TH neurons in the primary cultures after $1 \mathrm{~d}$ in vitro (DIV) requires explanation. One pos- sibility is that degradation of $\mathrm{TH}$ protein may require several days, as demonstrated previously (Cho et al., 1996).

However, the presence of previously synthesized $\mathrm{TH}$ protein does not account for the increase in the number of TH-containing cells in unstimulated cultures after an additional 2 DIV. The developmental origin of TH neurons in olfactory bulb in vivo may be relevant. $\mathrm{TH}$ expression was found only after dopaminergic neurons, which derive from the anterior subventricular zone and migrate into the olfactory bulb (Betarbet et al., 1996), reached the periglomerular region in which they received afferent stimulation (McLean and Shipley, 1988; Baker and Farbman, 1993). Thus, the increased number of TH-immunostained neurons after 2 DIV could be a consequence of $\mathrm{TH}$ protein synthesis in migrating cells that received afferent stimulation before dissociation but before completion of the transduction program. The formation of extensive processes also suggested that an intrinsic neuronal maturation program occurred during this time. In addition, either low levels of synaptic activity (Murphy et al., 1991) or low concentrations of glutamic acid, the putative receptor cell afferent transmitter (Berkowicz et al., 1994), in the cultures could induce TH synthesis in an already committed population of cells.

\section{$\mathrm{KCl}$-induced increase in cells expressing $\mathrm{TH}$}

Treatment of the cultures with a depolarizing concentration of $\mathrm{KCl}$ produced a further 2.5 -fold increase in the number of $\mathrm{TH}$ expressing neurons. This is the first report of a direct effect of membrane depolarization on the number of $\mathrm{TH}$ neurons in primary olfactory bulb cultures. The only previous study, performed on cultures prepared from embryonic day 16 rat embryos before few, if any, TH neurons have been generated, required pretreatment with the opiate antagonist nalaxone before an effect of depolarization could be demonstrated (McMillian et al., 1994). Thus, both differences in culture conditions and embryonic age could account for the requirement for opiate antagonists to induce $\mathrm{TH}$ expression. Importantly, the $\mathrm{TH}$ induction was not a consequence of a generalized increase in the number of neurons, glia, or total cells.

At issue is the origin of the newly demonstrable TH-containing neurons. A likely source could be a population of cells committed to express TH in vivo (Denis-Donini, 1989; Betarbet et al., 1996) but have not yet received afferent stimulation, which is then mimicked in vitro by the $\mathrm{KCl}$ treatment. In addition, selective effects on proliferation of $\mathrm{TH}$-containing neurons also could occur, because division of cells expressing a neuronal phenotype was found during their migration from the anterior subventricular zone to the olfactory bulb (Menezes et al., 1995). Last, prolonged neuronal survival specific to the TH-expressing cells also may contribute to the increase. However, although depolarization was shown to promote neuronal survival (Franklin et al., 1995), it also increased calcium entry into cells, a condition associated with cell death (Ellis et al., 1991; Cigola et al., 1997). Further studies are planned to evaluate a possible contribution of hyperplasia and apoptosis to the increase in TH-expressing cells. Surprisingly, short-term depolarization $(<36 \mathrm{hr})$ did not induce an increase in the number of $\mathrm{TH}$-immunostained cells, suggesting that prolonged stimulation is necessary to modulate the regulatory gene cascade required for induction of TH expression. This hypothesis is supported by a recent study showing that several days of odor stimulation are required to reverse the effects of sensory deprivation on olfactory bulb (Cummings et al., 1997). 

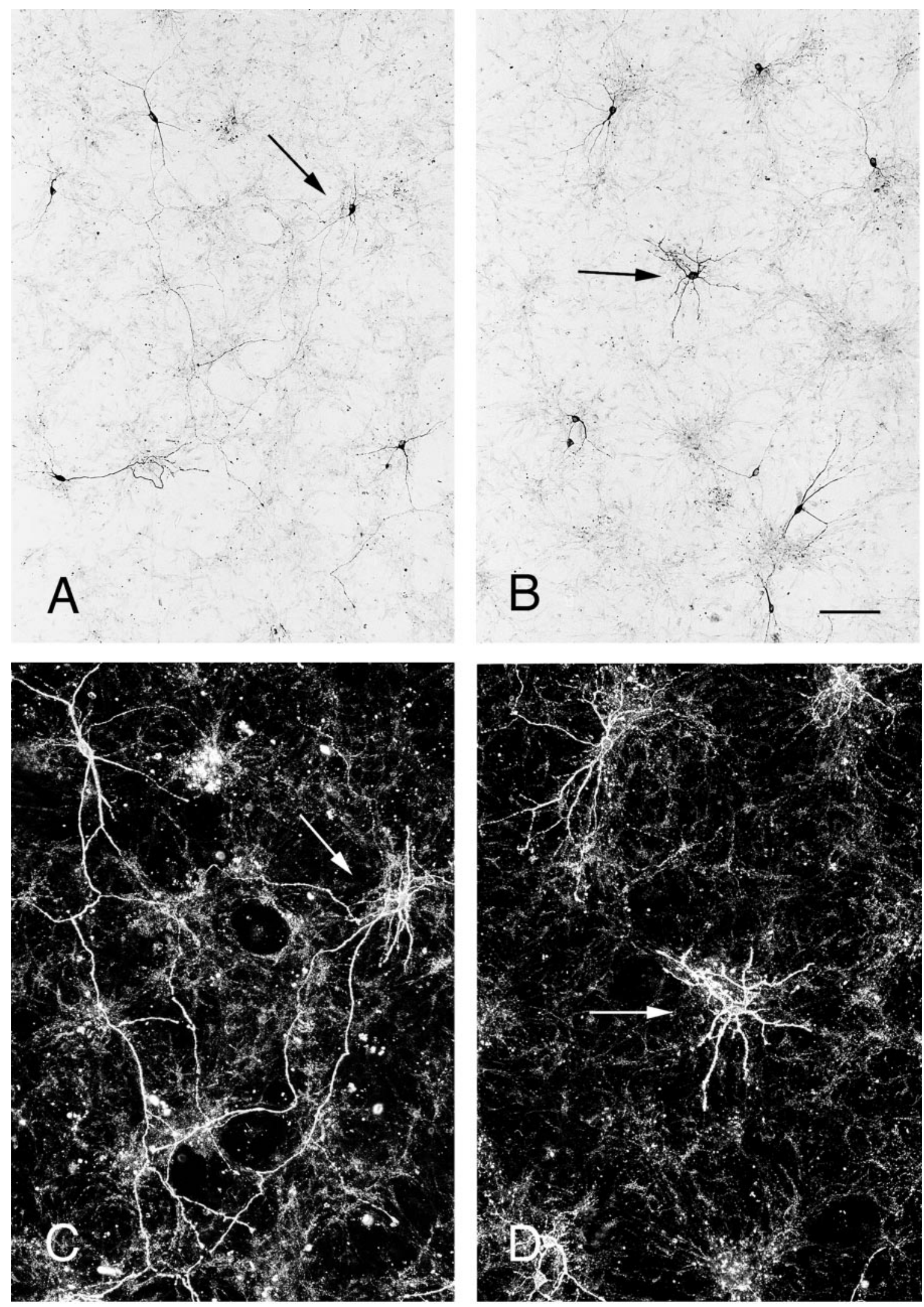

Figure 9. Forskolin-induced change in TH neuron number and neurite morphology. Forskolin $(B)$ produced an increase in the number of TH-immunopositive neurons compared with DMSO-treated control cultures $(A)$. Dark-field photomicrographs illustrate that in forskolin-treated cultures $(D)$ compared with DMSO $(C)$-treated cultures, TH neurons displayed a stellate morphology. In the latter cultures, immunostained processes were the same length as those observed in $\mathrm{NaCl}$ control cultures. Arrows in $A$ and $B$ indicate the same cells shown at higher magnification in $C$ and $D$. Scale bar (in $B$ ): $A, C, 100 \mu \mathrm{m} ; B, D, 65 \mu \mathrm{m}$. 


\section{Nifedipine blocks $\mathrm{KCl}$-induced increase in TH expression}

The current studies showed that nifedipine, an L-type calcium channel blocker, prevented the depolarization-induced increase in the number of TH-immunostained neurons but had no effect on control cultures, indicating that the induction of $\mathrm{TH}$ expression was mediated by an increase in intracellular calcium through these channels. A further direct demonstration of the role of this channel in inducing TH-expression was the ability of the L-type calcium channel agonist Bay K8644 to mimic the effects obtained with $\mathrm{KCl}$ treatment. A recent study demonstrating KCl-mediated $\mathrm{TH}$ regulation in primary sensory neurons also supported the role of L-type calcium channels in depolarization-induced TH expression (Brosenitsch et al., 1998). As indicated above, increases in intracellular calcium were shown to act via the CRE site in the TH promoter, which then acts like a CaRE (Sabban, 1997). In both adrenal medullary cultures and cell lines, depolarization induced TH expression (Kilbourne and Sabban, 1990; Kilbourne et al., 1992; Dahmer, 1995; Nagamoto-Combs et al., 1997). Calcium-chelating agents prevented the depolarization-mediated increase in $\mathrm{TH}$, and a calcium ionophore induced $\mathrm{TH}$ gene expression in PC12 cells. Previous studies also indicated that, in other systems including prenatally isolated olfactory bulb cultures, depolarization produced its effects via L-type calcium channels (McMillian et al., 1994). These channels were shown to play a minor role in mediating either spontaneous electrical activity or synaptically induced calcium currents in cortical neurons but an important role in producing synaptic activation of immediate early genes, such as c-fos (Murphy et al., 1991). Previous studies linked expression of early genes, including c-fos, to TH expression in the olfactory bulb (Guthrie and Gall, 1995a,b; Jin et al., 1996). Thus, these channels are key in coupling synaptic excitation to activation of transcription.

\section{Forskolin induction of TH expression}

The forskolin-induced 1.5-fold increase in TH-expressing neurons, in contrast to the response to depolarization, was not prevented by pretreatment with nifedipine. The lack of effect was unexpected, because combined treatment with forskolin and $\mathrm{KCl}$ was not more effective than $\mathrm{KCl}$ alone, suggesting a common mechanism. In addition, in other experimental systems, forskolin, by increasing cAMP levels, regulated both basal and inducible TH gene expression (Fader and Lewis, 1990; Tinti et al., 1996) and, like depolarization, acted via the CRE sequence present in the TH promoter (Fader and Lewis, 1990; Kim et al., 1994). The current data indicate that forskolin and depolarization induce TH-expression via different, possibly parallel but not additive, mechanisms.

\section{Alterations in neurite extension}

Depolarization and forskolin produced not only a change in the number of TH-containing neurons but in the morphology of their neurites. Depolarization dramatically reduced the length of the longest neurite, resulting in neurons with a stellate appearance. The response was not prevented by nifedipine pretreatment. These data are consistent with the effects of afferent stimulation on the morphology of TH-expressing cells in vivo during development. Migrating periglomerular cells, including those with ectopic expression of TH, displayed an unbranched leading neurite (Baker and Farbman, 1993; Luskin, 1993). Once in the periglomerular layer, the neurons expressed high levels of TH and developed highly branched dendritic processes (Baker and Farb- man, 1993; Betarbet et al., 1996). The morphological changes observed in the TH-expressing neurons in vitro may reflect a depolarization-mediated maturation similar to that which occurs in vivo. In addition, growth and differentiation may occur via different molecular pathways, as shown in a recent study in which depolarization promoted neuronal survival but did not mediate neurite growth (Franklin et al., 1995). The ability of nifedipine to prevent $\mathrm{TH}$ gene expression, but not the morphological changes, supports this hypothesis. Furthermore, in cultured frog olfactory bulb neurons, nifedipine blocked the depolarization-induced increase in intracellular calcium concentration in perikaryal, but not neuritic, compartments, indicating a segregation of channels and therefore possibly the consequences of their activation (Bischofberger and Schild, 1995).

\section{Summary}

The current studies are the first to demonstrate survival and differentiation of TH neurons in cultures obtained from neonatal olfactory bulbs. Furthermore, they demonstrate that depolarization, which mimics afferent stimulation in vivo, acts via L-type calcium channels to produce an increase in the number of $\mathrm{TH}$ expressing neurons. They also indicate that this model system can be used to delineate specific mechanisms regulating gene expression in olfactory bulb.

\section{REFERENCES}

Baker H (1990) Unilateral, neonatal olfactory deprivation alters tyrosine hydroxylase expression but not aromatic amino acid decarboxylase or GABA immunoreactivity. Neuroscience 36:761-771.

Baker H, Farbman AI (1993) Olfactory afferent regulation of the dopamine phenotype in the fetal rat olfactory system. Neuroscience 52:115-134

Baker H, Kawano T, Margolis FL, Joh TH (1983) Transneuronal regulation of tyrosine hydroxylase expression in olfactory bulb of mouse and rat. J Neurosci 3:69-78.

Baker H, Kawano T, Albert VR, Joh TH, Reis DJ, Margolis FL (1984) Olfactory bulb dopamine neurons survive deafferentiation induced loss of tyrosine hydroxylase. Neuroscience 11:605-615.

Baker H, Morel K, Stone DM, Maruniak JA (1993) Adult naris closure profoundly reduces tyrosine hydroxylase expression in mouse olfactory bulb. Brain Res 614:109-116.

Bayer SA (1983) [ $\left.{ }^{3} \mathrm{H}\right]$ Thymidine-radiographic studies of neurogenesis in the rat olfactory bulb. Exp Brain Res 50:329-340.

Berkowicz DA, Trombley PQ, Shepherd GM (1994) Evidence for glutamate as the olfactory receptor cell neurotransmitter. J Neurophysiol 71:2557-2561.

Betarbet R, Zigova T, Bakay RAE, Luskin MB (1996) Dopaminergic and gabaergic interneurons of the olfactory bulb are derived from the neonatal subventricular zone. Int J Dev Neurosci 14:921-930.

Bischofberger J, Schild D (1995) Differential spatial patterns of $\left[\mathrm{Ca}^{2+}\right]$ increase caused by $\mathrm{N}$ - and L-type $\left[\mathrm{Ca}^{2+}\right]$ channel activation in frog olfactory bulb neurones. J Physiol (Lond) 487:305-317.

Brosenitsch TA, Salgado-Commissariat D, Kunze DL, Katz DM (1998) A role for L-type calcium channels in developmental regulation of transmitter phenotype in primary sensory neurons. J Neurosci 18:1047-1055.

Brunjes PC, Frazier LI (1986) Maturation and plasticity in the olfactory system of vertebrates. Brain Res Rev 11:1-45.

Brunjes PC, Smith-Crafts LK, McCarty R (1985) Unilateral odor deprivation: effects on the development of olfactory bulb catecholamines and behavior. Dev Brain Res 22:1-6.

Cho JY, Min N, Franzen L, Baker H (1996) Rapid down-regulation of tyrosine hydroxylase expression in the olfactory bulb of naris-occluded adult rats. J Comp Neurol 369:264-276.

Cigola E, Kajstura J, Li B, Meggs LG, Anversa P (1997) Angiotensin II activates programmed myocyte cell death in vitro. Exp Cell Res 231:363-371.

Cummings DM, Henning HE, Brunjes PC (1997) Olfactory bulb recovery after early sensory deprivation. J Neurosci 17:7433-7440.

Dahmer MK (1995) Down-regulation of protein kinase C activity pref- 
erentially attenuates high $\mathrm{K}^{+}$-stimulated tyrosine hydroxylase activity in adrenal chromaffin cells cultured with insulin-like growth factor-1. Neurosci Lett 201:99-102.

Debus E, Weber K, Osborn M (1983) Monoclonal antibodies specific for glial fibrillary acidic (GFA) protein and for each of the neurofilament triplet polypeptides. Differentiation 25:193-203.

Denis-Donini S (1989) Expression of dopaminergic phenotypes in the mouse olfactory bulb induced by the CGRP. Nature 339:701-703.

Ellis RE, Yuan J, Horvitz HR (1991) Mechanisms and functions of cell death. Annu Rev Cell Biol 7:663-698.

Fader D, Lewis EJ (1990) Interaction of cyclic AMP and cell-cell contact in the control of tyrosine hydroxylase RNA. Mol Brain Res $8: 25-29$.

Franklin JL, Sanz-Rodriguez C, Juhasz A, Deckwerth TL, Johnson EMJ (1995) Chronic depolarization prevents programmed death of sympathetic neurons in vitro but does not support growth: requirement for $\mathrm{Ca}^{2+}$ influx but not Trk activation. J Neurosci 15:643-664.

Fung BP, Yoon SO, Chikaraishi DM (1992) Sequences that direct rat tyrosine hydroxylase gene expression. J Neurochem 58:2044-2052.

Gesteland RC, Yancey RA, Farbman, AI (1982) Development of olfactory receptor neuron selectivity in the rat fetus. Neuroscience 7:3127-3136.

Grill RJ, Pixley SK (1997) In vitro generation of adult rat olfactory sensory neurons and regulation of maturation by coculture with CNS tissues. J Neurosci 17:3120-3127.

Guthrie KM, Gall CM (1995a) Functional mapping of odor-activated neurons in the olfactory bulb. Chem Senses 20:272-282.

Guthrie KM, Gall CM (1995b) Odors increase Fos in olfactory bulb neurons including dopaminergic cells. NeuroReport 6:2145-2149.

Guthrie KM, Wilson DA, Leon M (1990) Early unilateral deprivation modifies olfactory bulb function. J Neurosci 10:3402-3412.

Guthrie KM, Anderson AJ, Leon M, Gall C (1993) Odor-induced increases in c-fos mRNA expression reveal an anatomical "unit" for odor processing in olfactory bulb. Proc Natl Acad Sci USA 90:3329-3333.

Halasz N, Ljungdahl A, Hokfelt T, Johansen O, Goldstein M, Park DH, Biberfield P (1977) Transmitter histochemistry of the rat olfactory bulb. I. Immunohistochemical localization of monoamine synthesizing enzymes. Support for intrabulbar, periglomerular dopamine neurons. Brain Res 126:455-474.

Hinds JW (1968) Autoradiographic study of histogenesis in the mouse olfactory bulb. I. Time of origin of neurons and neuroglia. J Comp Neurol 134:287-304.

Iacovitti L, Evinger MJ, Stull ND (1992) Muscle-derived differentiation factor increases expression of the tyrosine hydroxylase gene and enzyme activity in cultured dopamine neurons from the rat midbrain. Mol Brain Res 16:215-222.

Jin BK, Franzen L, Baker H (1996) Regulation of c-Fos mRNA and fos protein expression in olfactory bulbs from unilaterally odor-deprived adult mice. Int J Dev Neurosci 14:971-982.

Kilbourne EJ, Sabban EL (1990) Differential effect of membrane depolarization on levels of tyrosine hydroxylase and dopamine betahydroxylase mRNAs in PC12 pheochromocytoma cells. Mol Brain Res 8:121-127.

Kilbourne EJ, Nankova BB, Lewis EJ, McMahon A, Osaka H, Sabban DB, Sabban EL (1992) Regulated expression of the tyrosine hydroxylase gene by membrane depolarization. J Biol Chem 267:7563-7569.

Kim K-S, Lee MK, Carroll J, Joh TH (1993) Both the basal and inducible transcription of the tyrosine hydroxylase gene are dependent upon a cAMP response element. J Biol Chem 268:15689-15695.

Kim K-S, Tinti C, Song B, Cubells JF, Joh TH (1994) Cyclic AMPdependent protein kinase regulates basal and cyclic AMP-stimulated but not phorbol ester-stimulated transcription of the tyrosine hydroxylase gene. J Neurochem 63:834-842.

Kosaka T, Kosaka K, Hama K, Wu J-W, Nagatsu I (1987) Differential effect of functional olfactory deprivation on the GABAergic and catecholaminergic traits in the rat main olfactory bulb. Brain Res 413:197-203.

Lazaroff M, Patankar S, Yoon SO, Chikaraishi DM (1995) The cyclic AMP response element directs tyrosine hydroxylase expression in catecholaminergic central and peripheral nervous system cell lines from transgenic mice. J Biol Chem 270:21579-21589.

Luskin MB (1993) Restricted proliferation and migration of postnatally generated neurons derived from the forebrain subventricular zone. Neuron 11:173-189.

McLean JH, Shipley MT (1988) Postmitotic, postmigrational expression of tyrosine hydroxylase in olfactory bulb dopaminergic neurons. J Neurosci 8:3658-3669.

McMillian MK, Mullis SB, Wu G-C, Hudson PM, Pennypacker KR, Hong J-S (1994) Regulation of tyrosine hydroxylase in olfactory bulb cultures: selective inhibition of depolarization-induced increase by endogenous opioids. Brain Res 685:105-111.

Menezes JRL, Smith CM, Nelson KC, Luskin MB (1995) The division of neuronal progenitor cells during migration in the neonatal mammalian forebrain. Mol Cell Neurosci 6:496-508.

Miller RJ (1987) Multiple calcium channels and neuronal function. Science 235:46-52.

Murphy TH, Worley PF, Baraban JM (1991) L-type voltage-sensitive calcium channels mediate synaptic activation of immediate early genes. Neuron 7:625-635.

Nadi NS, Head R, Grillo M, Hempstead J, Granno-Reisfeld N, Margolis FL (1981) Chemical deafferentation of the olfactory bulb; plasticity of the levels of tyrosine hydroxylase, dopamine and norepinephrine. Brain Res 213:365-377.

Nagamoto-Combs K, Piech KM, Best JA, Sun B, Tank W (1997) Tyrosine hydroxylase gene promoter activity is regulated by both cyclic AMP-responsive element and AP1 sites following calcium influx. J Biol Chem 272:6051-6058.

Nowycky MC, Fox AP, Tsien RW (1985) Three types of neuronal calcium channel with different calcium sensitivity. Nature 316:440-443.

Sabban EL (1997) Control of tyrosine hydroxylase gene expression in chromaffin and PC12 cells. Semin Cell Dev Biol 8:101-111.

Saji M, Blau AD, Volpe BT (1996) Prevention of transneuronal degeneration of neurons in the substantia nigra reticulata by ablation of the subthalamic nucleus. Exp Neurol 141:120-129.

Sheng M, Greenberg ME (1990) The regulation and function of c-fos and other immediate early genes in the nervous system. Neuron 4:477-485.

Sheng M, McFadden G, Greenberg ME (1990) Membrane depolarization and calcium induce c-fos transcription via phosphorylation of transcription factor CREB. Neuron 4:571-582.

Stachowiak MK, Goc A, Hong JS, Poisner A, Jiang H-K, Stachowiak EK (1994) Regulation of tyrosine hydroxylase gene expression in depolarized non-transformed bovine adrenal medullary cells: second messenger systems and promoter mechanisms. Mol Brain Res 22:309-319.

Stone DM, Wessel T, Joh TH, Baker H (1990) Decrease in tyrosine hydroxylase, but not aromatic L-amino acid decarboxylase, messenger RNA in rat olfactory bulb following neonatal, unilateral odor deprivation. Mol Brain Res 8:291-300.

Stone DM, Grillo M, Margolis FL, Joh TH, Baker H (1991) Differential effect of functional olfactory bulb deafferentation on tyrosine hydroxylase and glutamic acid decarboxylase messenger RNA levels in rodent juxtaglomerular neurons. J Comp Neurol 311:223-233.

Takeshima T, Shimoda K, Johnston JM, Commissiong JW (1996) Standardized methods to bioassay neurotrophic factors for dopaminergic neurons. J Neurosci Methods 67:27-41.

Tinti C, Conti B, Cubells JF, Kim K-S, Baker H, Joh TH (1996) Inducible cAMP early repressor can modulate tyrosine hydroxylase gene expression after stimulation of cAMP synthesis. J Biol Chem 41:25375-25381.

Trombley PQ, Westbrook GL (1990) Excitatory synaptic transmission in primary cultures of rat olfactory bulb. J Neurophysiol 64:598-606

Volpe BT, Blau AD, Wessel TC, Saji M (1995) Delayed histopathological neuronal damage in the substantia nigra compacta (nucleus A9) after transient forebrain ischaemia. Neurobiol Dis 2:119-127.

Wallenstein S, Zucker CL, Fleiss JL (1980) Some statistical methods useful in circulation research. Circ Res 47:1-9.

Weiser M, Baker H, Wessel T, Joh TH (1993) Differential spatial and temporal gene expression in response to axotomy and deafferentation following transection of the medial forebrain bundle. $\mathrm{J}$ Neurosci 13:3472-3484.

Yoon SO, Chikaraishi DM (1992) Tissue-specific transcription of the rat tyrosine hydroxylase gene requires synergy between an AP-1 motif and an overlapping E Box-containing dyad. Neuron 9:55-67. 